\title{
ESTIMATION OF CROSSBREEDING EFFECTS FOR DOE TRAITS IN CROSSING OF BAUSCAT AND BALADI RED RABBITS \\ Attalah, G.E.Y ${ }^{1}$; A. Farid ${ }^{2}$ and M.G. Gharib' \\ 'Dept. of Anim. Prod., Fac. of Agric., Al-Azhar Univ., Nasr City, Egypt \\ ${ }^{2}$ Anim. Prod. Res. Institute, Ministry of Agric., Dokki, Cairo, Egypt.
}

\section{ABSTRACT}

A crossbreeding experiment was carried out, which involving Baladi Red (BR) and Bauscat $(B)$ rabbits to estimate direct heterosis $\left(H^{\prime}\right)$, maternal additive $\left(G^{M}\right)$ and direct additive $\left(\mathrm{G}^{\prime}\right)$ effects on doe traits (reproductive and litter traits). The doe traits of 690 litters (NSC, GL, LSB, NBA, LSW, LWB, LWW and LWG) were analyzed using a linear mixed model. Mating group's effect on doe traits were non-significant except NSC $(P \leq 0.05)$. Results were in favour of Bauscat rabbit for NBA, LWB, LWW and LWG traits. Crossbreeding between Bauscat and Baladi Red rabbits was associated with significant positive direct heterotic effect on NSC, LWW and LWG traits $(P \leq 0.05)$, direct heterosis estimates were positive for all doe traits studied except NSC. Direct additive effect for doe traits were not significant except NSC ( $P \leq 0.001)$. Linear functions were in the favour of Bauscat-sired rabbits. Maternal additive effect was also not-significant except NSC ( $P \leq 0.001$ ), in favour of local Baladi Red rabbits (as a dam breed) except in the NSC and LWG traits.

Keywords:Egyptian Baladi Red rabbits, crossbreeding, Heterotic effect, maternal additive effect, direct additive effect.

\section{INTRODUCTION}

Crossing native Egyptian breeds of rabbits with exotic ones was associated, in most cases, with an improvement in doe reproductive and litter traits Afifi et al., 1994 and Khalil et al, 1995). Crossbreeding among available breeds (e.g. Baladi, Baladi Red, Baladi Black, Baladi White) has been extensively used in Egypt (Afifi, 1971; El-Qen, 1988; Afifi and Khalil, 1989; El-Desoki, 1991) whereby existing breed differences from a heterotic and complementary standpoint are utilized. Breed differences, direct and maternal heterosis, maternal additive affects and direct additive effect from crossbreeding experiments of rabbits were shown to be important for reproductive performance of doe rabbits. Therefore, this study was conducted to evaluate the importance of heterosis, maternal and direct additive effect on some reproductive and litter traits performances in crossbreeding experiment involving Bauscat and Baladi Red rabbits.

\section{MATERIALS AND METHODS}

The experimental work of this study was carried out in the Experimental Rabbit flock maintained by the Department of Animal Production, Faculty of Agriculture, Al-Zahra University in Nasr City, Cairo, Egypt for three consecutive years of starting in September1998 till October 2001. 
The local Egyptian breed of rabbits Baladi Red, (BR) and Bauscat, (B) as exotic breed were used in the present study. According to the breeding plan, the does were mated with bucks of other breed, bucks were assigned at random to does with a restriction to avoid full-sib, half-sib and parent offspring matings. Each buck was allowed to be sire of all litters given by 3-5 does throughout the experimental period. Therefore the breeding plan permitted simultaneous production of $\mathrm{BB}$, BRBR, $1 / 2 \mathrm{~B}^{1} / 2 \mathrm{BR}$ and $1 / 2 B R^{1} / 2 B$ litters. Distribution of breeding does and bucks as well as number of litters are presented in Table1. Culled or dead does and bucks during the experimental period were replaced randomly by their substitutes from the same breed from the original stock.

Table 1. Mating groups and number of bucks, does and litters used

in the study.

\begin{tabular}{|llccc|}
\hline \multicolumn{2}{|c}{ Mating group } & \multicolumn{3}{c|}{ Number of } \\
\hline Buck & \multicolumn{1}{c}{ Doe } & Buck & Doe & Litters \\
\hline Bauscat & Bauscat & 14 & 47 & 203 \\
Baladi Red & Baladi Red & 13 & 44 & 171 \\
Bauscat & Baladi Red & 13 & 44 & 174 \\
Baladi Red & Bauscat & 14 & 52 & 142 \\
Total & & 54 & 187 & 690 \\
\hline
\end{tabular}

Rabbits were raised in a semi-closed rabbitry. Breeding does and bucks were housed separately in individual wired-cages with standard dimensions arranged in double-tier batteries. Cage of each doe was provided with a metal nest box for kindling. Some bucks were mated to 3-4 does of the same breed. Each doe was palpated 10 days thereafter to determine pregnancy. The failed to conceive doe were returned to the same mating buck at the day of test. Weaning were at (28 days after birth), young rabbits were sexed, tattooed and transferred to growing batteries to be housed in groups ( 3 to 4 individuals) in standard progeny wire cages by Feeding hoppers and drinking nipples were used. The rabbits were fed ad-libitum on commercial pelleted ration, which provide $16.3 \%$ crude protein, $13.2 \%$ crude fibers and $2.5 \%$ fat. Berssem was supplied at midday in winter only, clean water was available all time. Cages of all animals were cleaned and disinfected before each kindling regularly. Manure was collected daily and removed outside the rabbitry.

Data for doe traits (NSC, GL, LSB, NBA, LSW, LWB, LWW and LWG) were analyzed using the following mixed mathematical model:

$Y_{i k l m n}=\mu+M_{i}+S_{i k}+Y_{l}+S_{m}+P_{n}+(S e Y)_{m l}+(P Y)_{n l}+e_{i k l m n p}$ Where:

Yiklmnp $=$ The observation on the iklmnpth doe traits;

$\mu \quad=$ Overall mean, common element to all observations;

$\mathrm{Mi}_{\mathrm{i}} \quad=$ fixed effect of the $\mathrm{ith}$ mating group;

$\mathrm{S}_{\mathrm{ik}} \quad=$ random effect of $\mathrm{k}^{\text {th }}$ sire nested within the fixed effect of the $i^{\text {th }}$ mating group and

$Y_{1}=$ fixed effect of the th year of kindling

$\mathrm{Se}_{\mathrm{m}} \quad=$ fixed effect of the $\mathrm{m}^{\mathrm{th}}$ season of kindling;

$\mathrm{P}_{\mathrm{n}} \quad=$ fixed effect of the $\mathrm{n}^{\text {th }}$ parity; 

$(\mathrm{SeY})_{\mathrm{ml}}=$ fixed effect of interaction between the $\mathrm{m}^{\text {th }}$ season of kindlinfand th year of kindling;
$(P Y)_{n l} \quad=$ fixed effect of interaction between the $n^{\text {th }}$ parity and lth year of kindling and
eiklmnp = Residuel random deviation assumed to be independently randomly distributed, i.e. N.D $\left(0, \sigma^{2} e\right)$.

Genetic model and estimation of crossbreeding effects:

Cossbreeding effects (maternal additive, direct additive and direct heterosis) on different traits were estimated according to the following genetic model such genetic model permits to derive a selected set of linear contrasts (Harvey, 1990).

The following linear contrasts of mating type least-squares means were computed to quantify different attributable due to sire breed, dam breed and direct heterotic effect:

Purebred differences:

$\left\{\left(G^{i} B+G^{m} B\right)-\left(G^{i} B R+G^{m} B R\right)\right\}=(B \times B)-(B R \times B R)$.

Direct heterosis effect:

$\mathrm{H}^{\mathrm{i}} \mathrm{B}_{\mathrm{BR}}=\{(\mathrm{B} \times \mathrm{BR}+\mathrm{BR} \times \mathrm{B})-(\mathrm{B} \times \mathrm{B}+\mathrm{BR} \times \mathrm{BR})\}$.

Direct additive effect:

$\left(G^{i} B\right)=\{[(B \times B)+(B \times B R)]-[(B R \times B R)+(B R \times B)]\}$.

Maternal additive effect:

$\left(G^{m} B\right)=[(B \times B R)-(B R \times B)]$.

Where:-

$\mathrm{G}^{\mathrm{i}}$ and $\mathrm{G}^{\mathrm{m}}$ represent direct additive and maternal additive effects, respectively, of the subscripted breed (genetic) group. Each single degree of freedom contrast was tested for significance with the Student's t-test.

\section{RESULTS AND DISCUSSION}

\section{Mating groups:}

Mating groups effect on the doe traits (reproductive and litter traits) are given in tables (2, 3\& 4). Number of services per conception (NSC) was affected significantly $(\mathrm{P} \leq 0.05)$ by mating groups. These results are in agreement with those reported by Youssef (1992). However Gestation length (GL) did not differ significantly among the four mating groups of the present study. Similar findings were observed by Nayera et al, (1999), Khalil and Afifi (2000). However, for all litter traits studied (LSB, NBA, LSW, LWB, LWW and LWG) mating groups had non-significant effect. The same results was observed by Nayera et al., (1999), Khalil and Afifi (2000) and Abd El-Aziz et al (2002), who found that mating-group effect on most doe litter traits studied, were non-significant.

Least squares means of the doe traits of mating groups in tables (2, 3\& 4). Showed that B $\times$ BR mating gave the lowest means for NSC and the largest size and heaviest weight of litters. These results might indicate assort of heterotic effect. 
Attalah, G.E.Y et al.

Table 2. Estimates of mating groups Mean $\pm S E$, purebred difference, heterosis $\left(H^{i}\right)$, maternal $\left(G^{m}\right)$ and direct additive effects $\left(G^{i}\right)$ on some doe reproductive traits. Traits Reproductive traits

\begin{tabular}{|c|c|c|c|}
\hline \multirow[t]{2}{*}{ Traits } & \multicolumn{3}{|c|}{ Reproductive traits } \\
\hline & & NSC & GL \\
\hline & No. & Mean \pm SE & Mean \pm SE \\
\hline Mating groups & & & \\
\hline$B \times B$ & 203 & $1.5 \pm 0.05$ & $30.0 \pm 0.08$ \\
\hline $\mathrm{BR} \times \mathrm{BR}$ & 171 & $1.5 \pm 0.06$ & $31.0 \pm 0.09$ \\
\hline$B \times B R$ & 175 & $1.3 \pm 0.06$ & $31.2 \pm 0.09$ \\
\hline$B R \times B$ & 185 & $1.5 \pm 0.06$ & $31.1 \pm 0.08$ \\
\hline Significant & & & ns \\
\hline Purebred difference & & & \\
\hline $\begin{array}{l}\text { Bauscat us Baladi Red } \\
\text { Heterosis }\left(\mathrm{H}^{\mathrm{i}}\right)\end{array}$ & & $-0.006 \pm 0.06 \mathrm{~ns}$ & $-0.045 \pm 0.10^{n s}$ \\
\hline$H^{i} B \times B R$ & $\begin{array}{c}\text { Unit } \\
\text { Percent }\end{array}$ & $\begin{array}{c}-0.109 \pm 0.04^{* * *} \\
-7.4 \%\end{array}$ & $\begin{array}{c}0.129 \pm 0.07^{\mathrm{ns}} \\
0.42 \%\end{array}$ \\
\hline $\begin{array}{l}\text { Maternal additive effect } \\
\left(\mathrm{Gm}_{\mathrm{B}}\right)\end{array}$ & & $0.1999 \pm 0.06^{* * *}$ & $-0.174 \pm 0.10^{n s}$ \\
\hline $\begin{array}{l}\text { Direct additive effect } \\
\left(\mathrm{G}^{\mathrm{i}} \mathrm{B}\right)\end{array}$ & & $-0.205 \pm 0.08^{\star \star \star}$ & $0.128 \pm 0.14^{\mathrm{ns}}$ \\
\hline
\end{tabular}

Table 3. Estimates of litter size traits of mating groups, purebred difference, heterosis $\left(\mathrm{H}^{\mathrm{i}}\right)$, maternal additive effect $\left(\mathrm{G}^{\mathrm{m}}\right)$ and direct additive effect $\left(\mathrm{G}^{\mathrm{i}}\right)$.

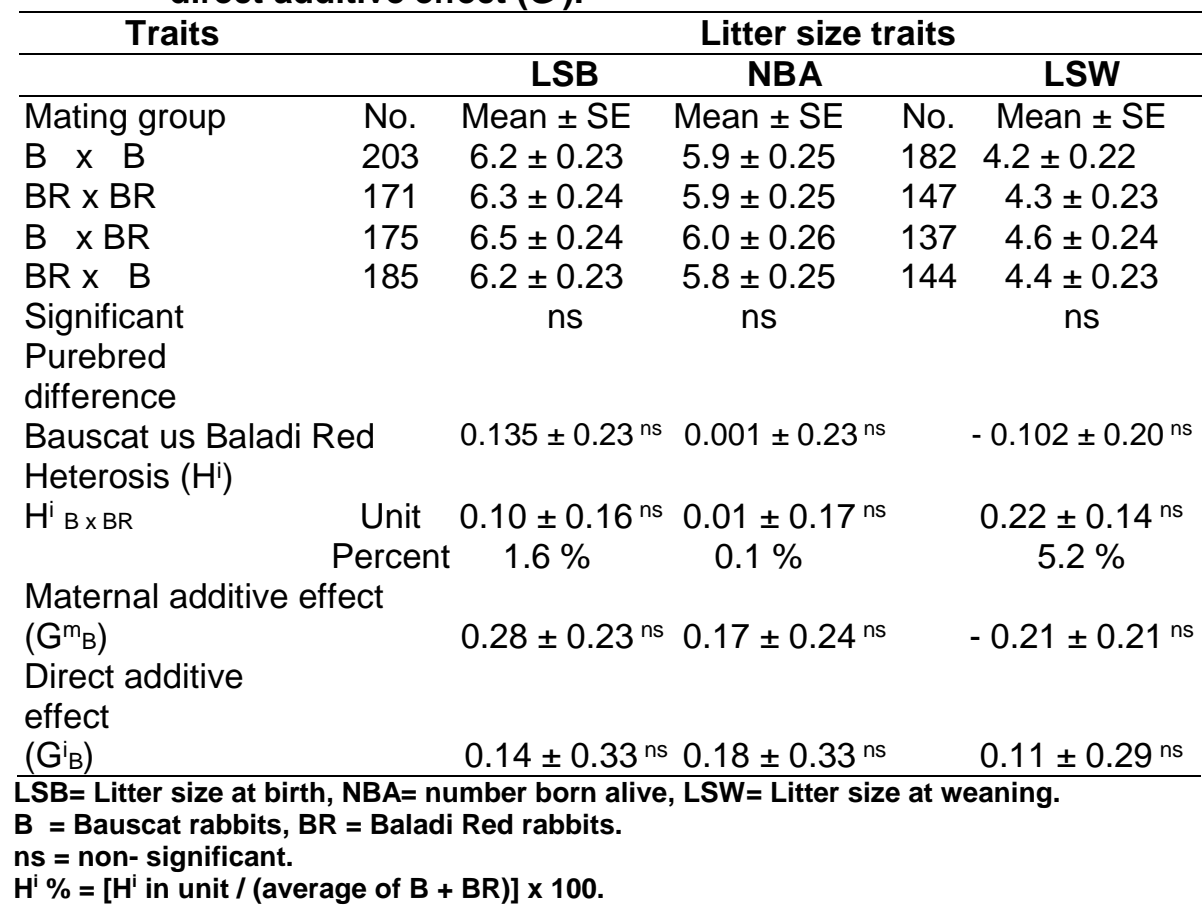

872 


\section{Purebred differences:}

Linear contrasts of Bauscat and Baladi Red rabbits are given in Tables (2, 3\& 4). However, the differences between them were nonsignificant for all doe traits (NSC, GL, LSB, NBA, LSW, LWB, LWW and LWG). Abd El-Aziz (1998), Gad (1998), Nayera et al. (1999) and Abd El-Aziz et al. (2002) with different breeds, found that the differences between these breeds were non-significant for most traits studied. On the other hand, Youssef (1992), Khalil et al. (1995) and Khalil et al (2002) showed that the differences between the different breeds studied were significant for most traits $(P \leq 0.05, P \leq 0.01$ or $P \leq 0.001)$. Results in Table (2, 3\& 4) were in favour of Bauscat rabbit for NBA, LWB, LWW and LWG, while it were in favour of Baladi Red rabbit for NSC, GL, LSB and LSW. In this respect, Youssef (1992) found that the linear contrasts of New Zealand White and Baladi Red were in favour of exotic (NZW) for most traits except preweaning mortality (PWM). However, Abd El-Aziz (1998). Nayera et al. (1999) and Abd El-Aziz et al (2002) found that the linear contrasts of New Zealand White and Gabli rabbits were in favour of Gabli rabbits for most traits studied.

Table 4. Estimates of litter weight traits of mating groups, purebred difference, heterosis $\left(H^{i}\right)$, maternal additive effect $\left(G^{m}\right)$ and direct additive effect $\left(G^{i}\right)$

\begin{tabular}{|c|c|c|c|c|c|}
\hline & & \multicolumn{4}{|c|}{ Litter weight traits } \\
\hline & & LWB & & LWW & LWG \\
\hline Mating group & No. & Mean \pm SE & No. & Mean \pm SE & Mean \pm SE \\
\hline$B \times B$ & 203 & $319.4 \pm 14.17$ & 182 & $1570.0 \pm 72.13$ & $1251.5 \pm 63.18$ \\
\hline $\mathrm{BR} \times \mathrm{BR}$ & 171 & $316.9 \pm 14.72$ & 147 & $1556.3 \pm 75.72$ & $1225.2 \pm 66.82$ \\
\hline $\mathrm{B} \times \mathrm{BR}$ & 175 & $351.4 \pm 14.96$ & 137 & $1695.8 \pm 80.49$ & $13425 \pm 71.08$ \\
\hline$B R \times B$ & 185 & $316.1 \pm 14.27$ & 144 & $1659.5 \pm 76.67$ & $1331.5 \pm 67.92$ \\
\hline $\begin{array}{l}\text { Significant } \\
\text { Purebred difference }\end{array}$ & & ns & & ns & ns \\
\hline $\begin{array}{l}\text { Bauscat us Baladi Red } \\
\text { Heterosis }\left(\mathrm{H}^{\mathrm{i}}\right)\end{array}$ & & $2.565 \pm 14.15^{n s}$ & & $13.72 \pm 73.90^{\mathrm{ns}}$ & $26.27 \pm 69.40^{\mathrm{ns}}$ \\
\hline $\mathrm{H}_{\mathrm{B} \times \mathrm{BR}}^{\mathrm{i}}$ & $\begin{array}{l}\text { Unit } \\
\text { Percent }\end{array}$ & $\begin{array}{c}15.54 \pm 53.90^{\mathrm{ns}} \\
4.9 \%\end{array}$ & & $\begin{array}{c}114.51 \pm 53.90^{\mathrm{ns}} \\
7.3 \%\end{array}$ & $\begin{array}{c}98.69 \pm 50.62^{\mathrm{ns}} \\
8.0 \%\end{array}$ \\
\hline $\begin{array}{l}\text { Maternal additive effect } \\
\left(G^{m}{ }_{B}\right)\end{array}$ & & $-\underset{n s}{35.22 \pm 14.40}$ & & $-36.30 \pm 78.96^{n s}$ & $11.03 \pm 74.16^{\mathrm{ns}}$ \\
\hline $\begin{array}{l}\text { Direct additive effect } \\
\left(G_{B}{ }_{B}\right)\end{array}$ & & $37.79 \pm 20.25^{\mathrm{ns}}$ & & $50.03 \pm 107.85^{\mathrm{ns}}$ & $37.89 \pm 101.29^{\mathrm{ns}}$ \\
\hline
\end{tabular}

LWB= Litter weight at birth, LWW= Litter weight at weaning,

LGW=pre- weaning litter gain.

$B=$ Bauscat rabbits, $B R=$ Baladi Red rabbits. Ns= non- significant.

$H^{i} \%=\left[H^{i}\right.$ in unit / (average of $\left.\left.B+B R\right)\right] \times 100$.

\section{Heterotic effect $\left(\mathrm{H}^{\mathrm{i}}\right)$ :}

Estimates of direct heterosis contrasts (calculated in actual units and as percentages) for different doe traits are presented in Tables (2, 3\& 4). These estimates indicate that crossbreeding between Bauscat and Baladi Red rabbits was resulted in significant heterotic effect on NSC $(P<0.001)$ and non-significant effect on GL. 
Estimates of direct heterosis effect on litter traits (LWW and LWG) was significant $(P \leq 0.05)$, while it was non-significant in (LSB, NBA, LSW and LWB). These estimates showed that the positive direct heterosis for all traits except NSC. These results evidenced the superiority of the crossbred for all traits over the purebred parental breeds, attributed to the presence of interbreed non-additive genetic effects Afifi (197I). In the same trend the heterotic effects most of litter and reproductive traits were recorded by (Youssef, 1992; Abd el-Aziz, 1998; Gad, 1998). However, crossbreeding seemed that it does not improve NSC, similarly Abd El-Aziz (1998) and Gad (1998), for litter size, (El-Dessoki (1991) and Youssef (1992), for litter weight, Afifi and Emara (1984) and Afifi and Khalil (1989). Results obtained in Table (4) showed that heterotic effects (units or percentages) was generally lower at birth than at weaning for litter weight (15.54 vs.114.51gm). This is expected since maternal and milking ability effects decreased with advance of litter age and consequently the non-additive genetic effects could express themselves later at weaning age more than earlier at kindling. Similar findings were obtained by Afifi and Emara (1984) and Afifi and Khalil (1989).

\section{Direct additive effect $\left(G^{i}\right)$ :}

Estimates of direct additive effect for doe traits (reproductive and litter traits) were presented in Tables (2, 3\& 4). The linear direct additive effect for all doe traits were not significant except NSC ( $P \leq 0.001)$. Thus, the contribution of buck breed effect in the inheritance of doe traits was little. Nayera et al, 1999; Khalil and Afifi, 2000; Abd El-Aziz et al, 2002 and Khalil et al, 2002) found non-significant breed-of-buck effect on most doe traits.

In general, the Bauscat-sired mating groups produced litters with larger size (LSB and NBA), heavier litter weight (LWB and LWW) as compared to BR-sired group. Thus, the trend of most doe traits was insignificantly in favour of Bauscat- sired rabbits. In this respect, Youssef (1992) reported that direct genetic effects on litter traits at birth was in favour of NZW but not Baladi Red and the reverse was true at weaning. Also, Garcia at (1982 a \&b) found that direct sire effects on litter traits at birth (LSB) for NZW-sired rabbits were remarkable than at weaning (LSW and LWW). In the same time, Rouvier (1979) found negative direct paternity effects of number born and weaned in NZW sired litters, while the corresponding positive estimates were observed in Californians

\section{Maternal additive effect:}

Maternal additive effect presented in Tables (2, 3\& 4) on all doe traits (reproductive and litter traits) were non-significant except NSC, LWB ( $P$ S0.001). Results of literature by El-Dessoki (1991) with New Zealand White, Californian and local Baladi rabbits reported a non-significant source of variation in gestation length. Abd El-Aziz (1998) and Nayera et al. (1999) non-significant source of variation in NSC and GL, while Youssef (1992) significant $(P \leq 0.05)$ in gestation length. Results of the crossbreeding experiments carried out in Egypt suggested that doe-breed effect was found to be significant $(P \leq 0.05, P \leq 0.01$ or $P \leq 0.001)$ by El Dessoki (1991) for NBA, LSW and LWW. Afifi and Emara (1984) for LWB, Attalah (1995) for LWB, 
Khalil and Afifi (2000) for LSB, LWB and LWW. However, Nayera et al, (1999); and Abd El-Aziz et al, (2002) indicated that maternal breed (additive) effects (expressed as the differences between reciprocal crosses) on litter traits at birth and during the pre-weaning period were not significant.

Mating of $B$ bucks with BR does give larger and heavier litters than those of the reciprocal mating $(B R \times B)$ for all doe traits. Although the maternal breed (additive) effects were not significant, the trends of most doe traits were in favour of local Baladi Red rabbits as a doe breed except NSC and LWG. Khalil et al (1995), Nayera et al (1999) and Abd El-Aziz et al (2002) found that BR damed litters recorded lower performance for NSC compared to $B$. The present findings might refer to that BR does might be comparable to those of the B ones in their maternity.

\section{REFERENCES}

Abd El-Aziz, M.M. (1998). Crossbreeding between Al-Gabali and New Zealand White rabbits in the North coast-belt of the Egyptian Western desert. Ph.D. Thesis, Fac. of Agric., Moshtohor, Zagazig Univ., Banha Branch, Egypt.

Abd El-Aziz, M.M.; Afifi, E, A.; Nayera, Z. Bedier; Azamel, A.A. and Khalil, M.H. (2002). Genetic Evaluation of milk production and litter weight traits in Gabali and New Zealand White rabbits and their crosses in a newly reclaimed area of Egypt. The $3^{\text {rd }}$ Sci. Con. on rabbit production in hot climates, 8-11 Oct. 2002, Hurghada, Egypt, 103-116.

Afifi, E.A. (1971). A study of some economical and productive characters in some strains of rabbits and their crosses. Ph.D. Thesis, Fac. Agric., Moshtohor, Zagazig Univ., Banha Branch, Egypt.

Afifi, E.A. and Emara, M.E. (1984). Litter weight in local Egyptian and exotic breeds of rabbits and their crosses, $3^{\text {rd }}$ World Rabbit Con., 4-8 April, Rome. Italy V I QGI,pp. 126-135.

Afifi, E.A. and Khalil, M.H. (1989). Observations on purebred and crossbred litters of Giza White and Grey Giant Flander rabbits in Egypt. J. Appli. Rabbit Res. 12:273-277.

Attalah, G.E.Y. (1995). Genetic analysis of the performance of some pure and crossbreds strains of rabbits. Ph.D. Thesis, Fac. of Agric., Al-Azhar Univ., Nasr-City, Cairo, Egypt.

El-Dessoki, A.E.M. (1991). Study of the effect of some genetic and environmental factors affecting meat yield from some foreign and local breeds of rabbits and their crosses. M.Sci. Thesis Fac.of Agric., Mansoura Univ., Egypt.

Gad, S.O.A. (1998). Evaluation of growth and production performance of AlGabli rabbits and their crosses under semi-arid conditions. M. Sci. Thesis, Fac. of Agric. Moshtohor, Zagazig Univ., Banha Branch, Egypt.

Garcia, F.; Baselga. M.; Blasco, A. and Deltoro, J. (1982a). Genetic analysis of some productive traits in meat rabbits. 1. Numeric traits. $2^{\text {nd }}$ World Con. on Genetics Applied to Livestock Production, October 1982, Madrid, Spain.7, 7: 557-562. 
Garcia, F.; Baselga. M.; Blasco, A. and Deltoro, J. (1982b). Genetic analysis of some productive traits in meat rabbits. II. Ponderal traits. $2^{\text {nd }}$ World Con. on Genetics Applied to Livestock Production. Oct. 1982, Madrid, Spain- 7, 7: 575-579.

Harvey, W.R. (1990). Users guide for LSMLMW. Mixed model least squares and maximum likelihood computer program. PC. Version 2. Ohio Slate Univ., Columbus, USA (mimeograph).

Khalil, M.H. and Afifi, E.A. (2000). Heterosis, maternal and direct additive effects for litter performance and post-weaning growth in Gabli rabbits and their crosses with New Zealand White. $7^{\text {th }}$ World Rrabbit Con., 4-7 July 2000 , Valencia Spain.

Khalil, M.H.; Afifi, E.A.; Youssef, Y.M.K. and Khadr, A.F. (1995). Heterosis, Maternal and direct genetic effects for litter performance and reproductive intervals in rabbits crosses. World Rabbit Sci.,3(3):99-105.

Khalil, M.H.; Afifi, E.A.; Farid, A. and Youssef, Y.M.K. (2002). Estimation of crossbreeding effects for some litter traits in crossing of New Zealand White with Egyptian Gabli rabbits. Egyptian J.Rabbit Sci.,12(2):143153.

Nayera, Z. Bedier; Afifi, E.A. and Gad, S.M. (1999). Genetic study of litter and doe reproductive traits in Gabli, Californian rabbits and their crosses under semi-arid conditions of Egypt. Minufiya J. Agric. Res., 24 (5): 1651-1666.

Rouvier, R. (1979). Physiological effects of selection on the aspects of ponderal and numerical productivity in domestic rabbits. Proceeding of Symposium held at Harrogate, July 1979, Commonwealth Agric., Bureau, UK.

Youssef, M.K. (1992). The productive performance of purebred and crossbred rabbits, M.Sci. Thesis, Fac. of Agric., Moshtohor, Zagazig Univ., Banha Branch, Egypt. 


\section{تقدير تأثير الخلط على بعض صفات أنثى الأرانب في خلطة أرانب البوسكات مع البلإي الأحمر \\ جمال الاين يوسف عطا الله' و احمد فريد محمود' و محمود غريب غريب محمد. '

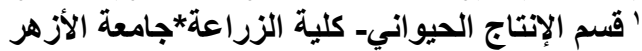

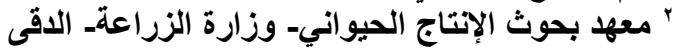

أجريت هذه الدراسـة في مزرعة الأرانب البحثبة بكلية الزراعة- جامعة الأزهر بمدينة

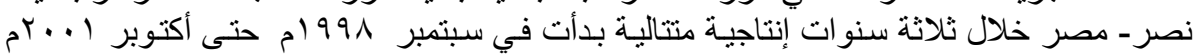

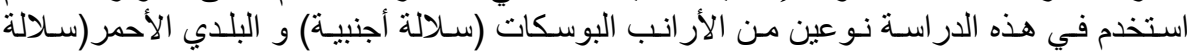

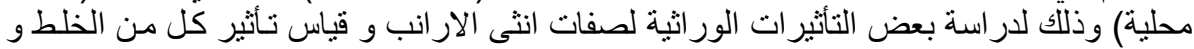

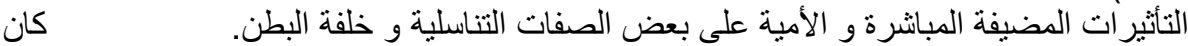

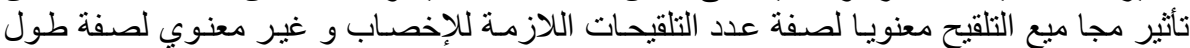

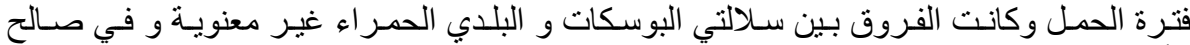

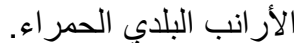

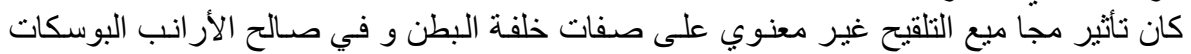

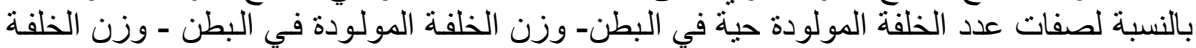

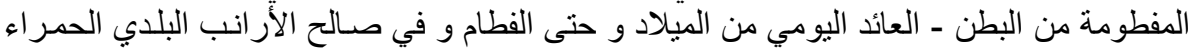
بالنسبة لصفات عدد الخلفة المولودة في البطن - عدد الخلفة الخفة المفطومة في البطن.

تأثير الخلط :

أدى الخلط بين سلالتي البوسكات و البلدي الحمر اء إلى تحسين عدد التلقيحات اللازمـة

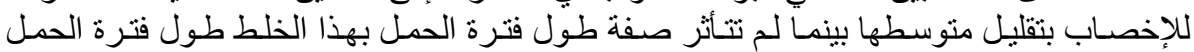

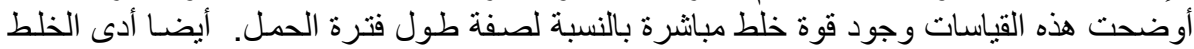

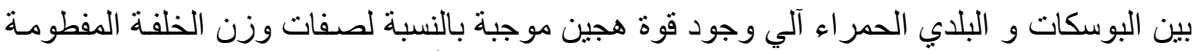

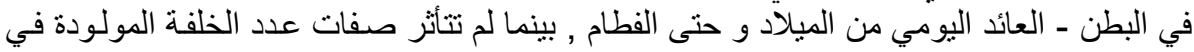

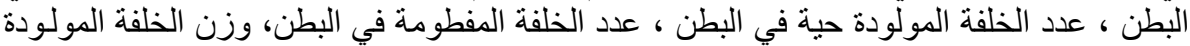

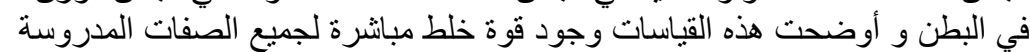

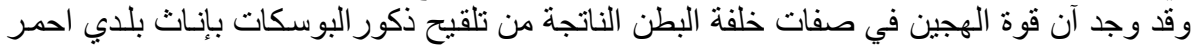
اكبر من نظيرتها للبطون الناتجة من التلقيح التئين العكسي.

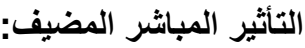

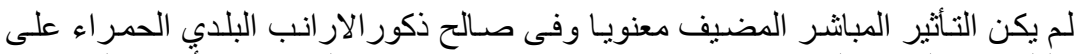

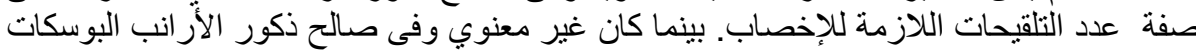

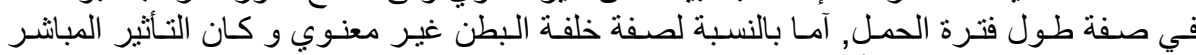
الكضيف في صالح ذكور الأرانب البوسكات بالنسبة لهذية لهذه الصفات جميعا.

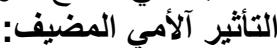

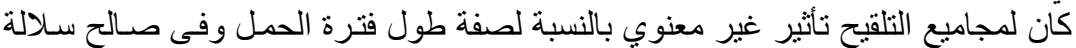

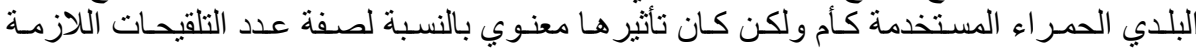

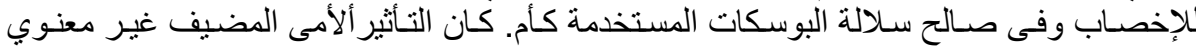

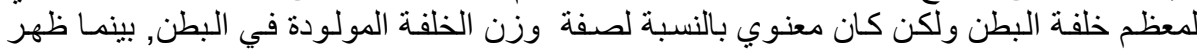
عكس ذللك عند استخدام سلالة البلدي الحمر اء كآم فيما عدا صفة العائد اليومي من المبلاد و حتى الئى 
Attalah, G.E.Y et al.

$\begin{array}{llllllll}871 & 873 & 875 & 877 & 871 & 873 & 875 & 877\end{array}$

878

P@FD 